\title{
PAUL'S LETTER TO THE PHILIPPIANS IN THE LIGHT OF DISUNITY IN THE CHURCH ${ }^{1}$
}

\section{Davorin Peterlin}

Paul's letter to the Philippians is ordinarily seen as reflecting a warm relationship between Paul and the congregation, and a similarly exemplary fellowship within the congregation, marred only by petty bickering. The purpose of the study is to demonstrate that, quite on the contrary, the theme of disunity is more widespread in Philippians than is usually acknowledged, and that it actually underlies the whole of Philippians. It is suggested that the situation of disunity in the church is the background against which Philippians is to be read.

The dissertation is divided into two parts. Part One draws attention to the distribution of the theme of disunity throughout much of the letter. Following the sequential order of Philippians I deal with the following main units: 1:1-11, 1:1226 ; 1:27-2:18, 3:1-4:1, 4:2,3. The following questions are addressed: What are the characteristics of disunity in the Philippian church? Which factors contributed to its emergence? Who are the participants? What can be concluded about the dynamics of their interaction? Can all these references be taken as facets of one and the same situation?

The findings suggest that some time prior to Philippians the church came under some kind of external pressure from the pagan environment (1:27-30), possibly in the form of social ostracism. Although active persecution is unlikely, the Philippian Christians apparently felt the pressure quite acutely. This forced the church to think through its understanding of the problem of suffering. Some Christians averred that their God could not possibly desire that any of his

${ }^{1}$ Davorin Peterlin, Paul's Letter to the Philippians in the Light of Disunity in the Church (Unpublished Ph.D. thesis, Aberdeen, 1992); supervisor: Professor Howard Marshall. 
true followers should suffer. This assumption was presumably partly rooted in, and carried over from, their former pagan religious conceptions. Others maintained that their new faith entailed suffering. The dispute involved a large number of Christians, but led to confusion rather than controversy.

Another factor informing the picture of the situation is the presence of a certain perfectionist streak in the church. Its precise nature unfortunately remains elusive, which makes it extremely difficult to gauge its role in, and pinpoint its specific contribution to, the controversy current at the time of Paul's letter. One thing seems certain though: those in the church who could be described as perfectionist were the same members who advocated the view that suffering was incompatible with true Christianity. Here we must assert another crucial point: this perfectionistic streak was not a carefully thought-out theological position; it existed in seminal form as 'tendencies' and 'inclinations'. Even for Paul, responding later with the letter there is no question of a theological aberration as he does not attack it in any way comparable to the manner in which he combats heretical views in other epistles. These perfectionistic tendencies did not represent the gist of the problem although they did feed into the situation.

Part Two starts with two topics relevant for establishing general historical context. One is the issue of the size, composition, and structure of the Philippian church. The other is Paul's policy toward the financing of his missionary endeavours through the acceptance of financial support in general, and in particular from the Philippians.

The real focus lies however on the collection of money to be sent as relief to Paul, as well as the mission of Epaphroditus. The two key texts are 2:25-30 and 4:10-20, and the principal questions here are: What kind of independent information about disunity do these sections supply? Are there traits parallel to those already observed in Part One? How does this episode fit into the wider framework of Philippians?

The objective is to establish whether these two topically interconnected texts also contain references and allusions to disunity in the church. It is thus found, independently of the discussion in Part One, that the collection of money for Paul 
went less than smoothly, and that the subsequent events also betrayed signs of disunity in the church. Moreover, there is tension between Epaphroditus and the church, and between Paul and the church.

A correlation with Part One suggests further similarities between paragraphs dealt with in Part Two and those in Part One. These include Paul's almost identical attitude to the readers characterised by deliberate neutrality, his involvement in the conflict and the presence in the church of an anti-Pauline sentiment, his affection and warmth with regard to the readers, and the conspicuous insignificance of theological factors indicating the primarily non-theological nature of the conflict. At the end it is suggested that Epaphroditus was also probably involved in the affair as a member of the church's leadership.

On this basis a hypothesis is advanced that these events surrounding the latest collection of support for Paul are to be seen as an aspect of the general situation of disunity and conflict in the church. In order to substantiate the hypothesis an interpretation of the whole epistle is required which combines, and accounts for, several factors: 1) confusion related to the place of suffering in the life of a Christian; 2) the reality of disunity and controversy in the Philippian church; 3) the fact that one of the parties harboured at least dissatisfaction if not open hostility against Paul; 4) the collection of the monetary support for Paul, the outcome of which was evidently understood, both by Paul and some in the church, as falling short of their potential and as less than commendable for the givers; 5) the resulting mission of Epaphroditus who was to make up for what was missing, but which resulted in aggravating the situation in the church; 6) Paul's cautious response alternating between overt gratitude and defensive statements reflecting his uneasiness over the whole affair.

The concluding chapter collates the findings and draws inferences. It suggests that discord in the church started with differing views on the place of suffering in the Christian life, that Paul's imprisonment provided an occasion for the aggravation of the conflict, that the power-struggle among the leadership revolved around the question whether or not to 
send support to Paul, and that Euodia and Syntyche who belonged to the church leadership were the main advocates of the opposing views. When the money is collected, Epaphroditus is sent to Paul to supplement the amount which is deemed inadequate by Paul's supporters in the church.

It is argued therefore that discord had three basic directions or forms: disunity among members; strife between (some) members and Epaphroditus; tension between (some) members and Paul. From these findings conclusions are drawn about the immediate occasion, the real occasion (reason) for the writing of Philippians, and the primary and secondary aims of the letter. 